\title{
Benthic foraminiferal assemblages from Kiritimati (Christmas) Island indicate human-mediated nutrification has occurred over the scale of decades
}

\author{
Jessica Carillii, ${ }^{1 *}$, Sheila Walsh ${ }^{2,3}$ \\ ${ }^{1}$ Institute for Environmental Research, Australian Nuclear Science and Technology Organization, Lucas Heights, \\ New South Wales 2234, Australia \\ ${ }^{2}$ Environmental Change Initiative, Brown University, Providence, Rhode Island 02912, USA \\ ${ }^{3}$ Present address: The Nature Conservancy, Arlington, Virginia 22203, USA
}

\begin{abstract}
Community assemblages of live and dead benthic foraminifera from Kiritimati (Christmas) Island, Kiribati, were used to investigate changes in nutrification before and after human occupation. Benthic foraminiferal assemblages have previously been shown to have strong empirical relationships with water quality: mixotrophic, symbiont-bearing foraminifera dominate in clear, nutrient-poor waters, while heterotrophic and/or opportunistic foraminifera are more prevalent in polluted or nutrified waters. After human occupation, the proportion of mixotrophic taxa decreased significantly at all sites on Kiritimati with the largest decreases observed at sites with the highest fishing pressure. These changes in the benthic foraminiferal assemblage indicate that nutrification has occurred on Kiritimati over the scale of decades, possibly due to changes in trophic structure and nutrient cycling caused by fishing.
\end{abstract}

KEY WORDS: Coral reefs · Trophic structure $\cdot$ Fishing $\cdot$ FORAM Index $\cdot$ Foraminifera $\cdot$ Nutrification $\cdot$ Kiritimati

\section{INTRODUCTION}

Numerous studies characterizing human impacts on corals reefs have found decreases in the total abundance of fish and reef-builders and in the average trophic level of the fish and benthic community (Hughes 1994, Gardner et al. 2003, Pandolfi et al. 2003, 2005, Bellwood et al. 2004, Newman et al. 2006, Sandin et al. 2008). However, also important are changes in microscopic communities including microbes and foraminifera. Understanding these changes is critical to understanding whole system changes on coral reefs, such as those associated with nutrification. Nutrification may occur through direct addition of nutrients (Dubinsky \& Stambler 1996) or indirectly through changes in trophic structure and nutrient cycling (Kitchell et al. 1979, Chapin et al. 1997). Previous work has shown that the relative abundances of heterotrophic bacteria and viruses increase with human impacts, such as nutrient pollution and fishing (Carlson et al. 2002, Dinsdale et al. 2008, Graham et al. 2011). Similarly, benthic foraminiferal communities change in response to reduced water quality on coral reefs (Hallock et al. 2003, Uthicke \& Nobes 2008), providing an as yet underutilized mechanism to test for nutrification on reefs. Here, we investigated changes in benthic foraminiferal communities at Kiritimati atoll associated with recent human occupation. Nutrification may have directly occurred due to untreated sewage runoff (Risk \& Erdmann 2000) or indirectly resulted from the effects of fishing on trophic structure (Dinsdale et al. 2008).

Benthic foraminifera are ubiquitous single-celled protists that typically form calcium carbonate tests (shells), either by direct secretion (biomineralization) or agglutinating particles, such as sand, from the 
environment. In some cases, foraminiferal tests make up the majority of marine sediments (e.g. Woodroffe \& Morrison 2001), but even when found in lower abundance, the record they leave in aquatic sediments is extremely useful for reconstructing past environmental conditions (Murray 2006). Similar to corals, some benthic foraminifera house photosynthetic symbionts of various kinds (including diatoms and dinoflagellates), and these mixotrophic foraminifera are typically dominant in clear, low-nutrient waters but decline in abundance with nutrification (Hallock 2000, Uthicke \& Altenrath 2010). Heterotrophic and opportunistic foraminifera tolerate waters with high turbidity and nutrients, as well as more stressful conditions such as high heavy metal concentrations and low oxygen (Murray 2006). The relative abundance of these groups in a sediment sample can therefore be used to investigate water quality (Hallock et al. 2003). Hallock et al. (2003) devised the 'FORAM Index' (FI) to place the relative abundance of the 3 groups on a scale from 1 to 10, with 1 being entirely composed of opportunistic species, and therefore indicative of high-nutrient or increased turbidity conditions, and 10 being entirely composed of symbiont-bearing species, indicating low-nutrient, low-turbidity conditions.

Studies using the FI have found that it was negatively correlated with increased nutrient and decreased light availability (Uthicke \& Nobes 2008) as well as sediment organic content and water column turbidity in inshore and mid-shelf back and forereefs on the Great Barrier Reef, Australia (Uthicke et al. 2010). Low FI values have also been associated with high heavy metal concentrations in Biscayne Bay, Florida, USA (Carnahan et al. 2008). Hallock et al. (2003) found that the FI declined over time around reefs in the Florida Keys and along a spatial gradient of nutrification and reef degradation in Puerto Rico. Hallock et al. (2003) found FI values $<2$ in areas where no coral reefs were supported, while in locations with marginal reef development, FI values fell between 2 and 4 . While the FI was originally constructed for use in the Caribbean, its application in the Pacific has also been successful (Schueth \& Frank 2008, Uthicke \& Nobes 2008, Narayan \& Pandolfi 2010, Uthicke et al. 2010).

Kiritimati, Line Islands, Republic of Kiribati, provides a unique opportunity to investigate changes in the benthic foraminiferal assemblage associated with nutrification due to human impacts. A permanent human population was first established at Kiritimati in the 1850s for copra production (Sandin et al. 2008). The population (and associated fishing and sewage impacts) on Kiritimati has increased exponentially since the 1970s due to a population re-settlement program that brings people from the capital, Tarawa, located $3300 \mathrm{~km}$ to the west (Sandin et al. 2008). Due to the pattern of settlement and oceanography, fishing on Kiritimati is mainly concentrated on the northern portion of the atoll, while upwelling is concentrated in the northwest (see Fig. 2; Walsh 2011). We hypothesized that changes in the FI could be used to test whether the recent arrival of humans on Kiritimati has caused nutrification.

Nutrification on Kiritimati could have occurred either indirectly through fishing by changing reef trophic structure and nutrient cycling, or directly via sewage runoff. Previous studies on Kiritimati reefs have found that moderate fishing was correlated with changes in the fish and benthic community structure, with comparatively fewer large, upper trophic level fish, lower live coral cover, and higher macroalgae and turf algal cover on more heavily fished reefs around Kiritimati (DeMartini et al. 2008, Walsh 2011) than on lightly fished reefs on Kiritimati and unfished reefs on other islands in the Line Islands archipelago (DeMartini et al. 2008, Sandin et al. 2008). In contrast to this pattern of declining trophic level in the fish and macro-benthic communities across more heavily fished reefs, there was an increase in the average trophic level in the microbial community (Dinsdale et al. 2008). The abundance of heterotrophic versus autotrophic bacteria and viruses was higher on more heavily fished reefs in Kiritimati compared to unfished reefs in the Line Islands (Dinsdale et al. 2008). These patterns could have also been partly explained by differences in upwelling across and within islands (Dinsdale et al. 2008, Sandin et al. 2008). However, fishing pressure was most strongly correlated with spatial differences in the abundances of most fish groups (top predators, carnivores, and herbivores) and crustose coralline algae around Kiritimati; patterns in both fishing and upwelling best explained spatial differences in planktivore fishes and macroalgae (Walsh 2011). The present study aimed to examine differences in water quality around Kiritimati that may be caused by temporal and spatial differences in fishing or sewage impacts, while controlling for spatial differences in oceanography, by comparing the live and dead assemblages of benthic foraminifera.

Nitrogen- and phosphorus-rich sewage runoff can cause direct nutrification on coral reefs (probably the best-studied example was at Kaneohe Bay, Hawaii, USA; Smith et al. 1981), but a growing body of literature has suggested that fishing may indirectly cause 
nutrification via several mechanisms (summarized in Fig. 1). Lower fish biomass means a reduction in this nutrient reservoir as well as a potential reduction in nutrient export to the sediments (e.g. through feces or detritus) or off the reef (e.g. via predation by pelagic animals; Kitchell et al. 1979), thereby increasing the available nutrient pool in the water column. In addition to altering the structure of the fish community (Pauly et al. 1998, Jennings et al. 1999), fishing may indirectly affect the rest of the reef ecosystem through changes in grazing (McClanahan \& Muthiga 1988, Dulvy et al. 2004). For example, overfishing of apex predators has led to increased planktivore populations, which reduced zooplankton and increased phytoplankton, impeding water clarity in the Black Sea (Daskalov 2002). Overfishing of herbivores can lead to a shift from coral dominance to turf and macroalgal dominance (e.g. McClanahan \& Shafir 1990, Hughes 1994, Mumby et al. 2006), which can reduce water quality in several ways. Nutrient levels themselves also play a role in controlling the competitive balance between fleshy algae and corals (LaPointe 1997, Burkepile \& Hay 2006) and may be more important for controlling turf algae than fishing (Vermeij et al. 2010). Recent work has found that organic matter released by algae, primarily in dissolved form, stimulated microbial activity and a drawdown of dissolved oxygen as opposed to organic matter released by corals, which is primarily in particulate form (mainly as mucus; Haas et al. 2010, Wild et al. 2010). Coral mucus acts to help transport particulates from the water column into the sediments (Huettel et al. 2006), while fish feces also helps export organic carbon and nutrients from the water col- umn to the benthos (Chartock 1983, Smriga et al. 2010). Reduced fish and coral populations should therefore reduce organic carbon and nutrient export to the sediment (Huettel et al. 2006, Smriga et al. 2010), allowing water column bacteria to remineralize these materials, again leading to water column nutrification.

We expected to find a higher relative abundance of mixotrophic foraminifera (high FI, indicating better water quality conditions) in the dead assemblage as compared to the live assemblage, if the arrival of humans had indeed increased nutrification. Spatial differences in the dead assemblage should be attributable only to differences in oceanography while spatial differences in the live assemblage should be attributable to both oceanography and human impacts. We expected that higher upwelling would be associated with a higher relative abundance of heterotrophic foraminifera. We also expected that sites that experienced greater increases in human impacts over time would show increases in the relative abundance of heterotrophic foraminifera. To test for nutrification due to fishing versus sewage runoff, we collected samples from a range of sites with different levels of fishing pressure both near and far from population centers.

\section{MATERIALS AND METHODS}

\section{Study location and nutrient driver metrics}

Kiritimati (Christmas) Island, Republic of Kiribati, is a large coral atoll in the central Pacific (Fig. 2), sur-

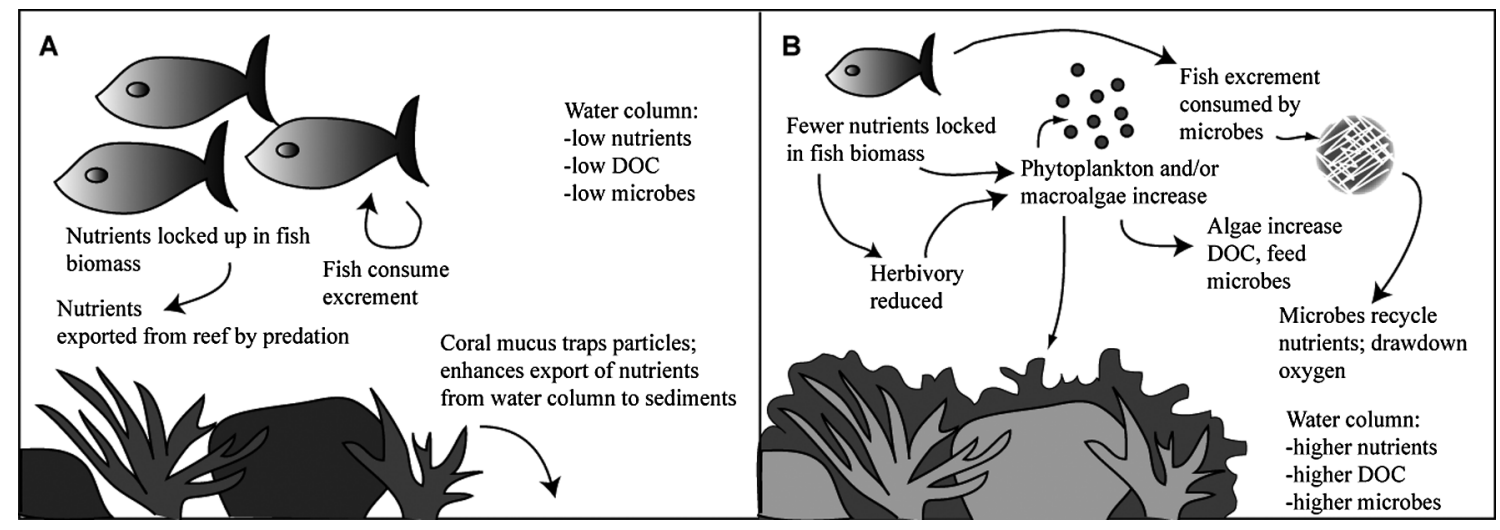

Fig. 1. Conceptual diagram of potential coupling mechanisms between trophic structure and water quality, based on studies referenced in the body of this paper. (A) Represents a healthy coral reef with abundant live corals and fish, and low nutrients, dissolved organic carbon (DOC), and microbes in the water column. (B) Represents a degraded coral reef where reduced herbivory and fewer fish allow algae (benthic macroalgae and turf and/or phytoplankton) to proliferate. Increased algae in turn release DOC and fuel water column microbes, which remineralize nutrients and drawdown oxygen 


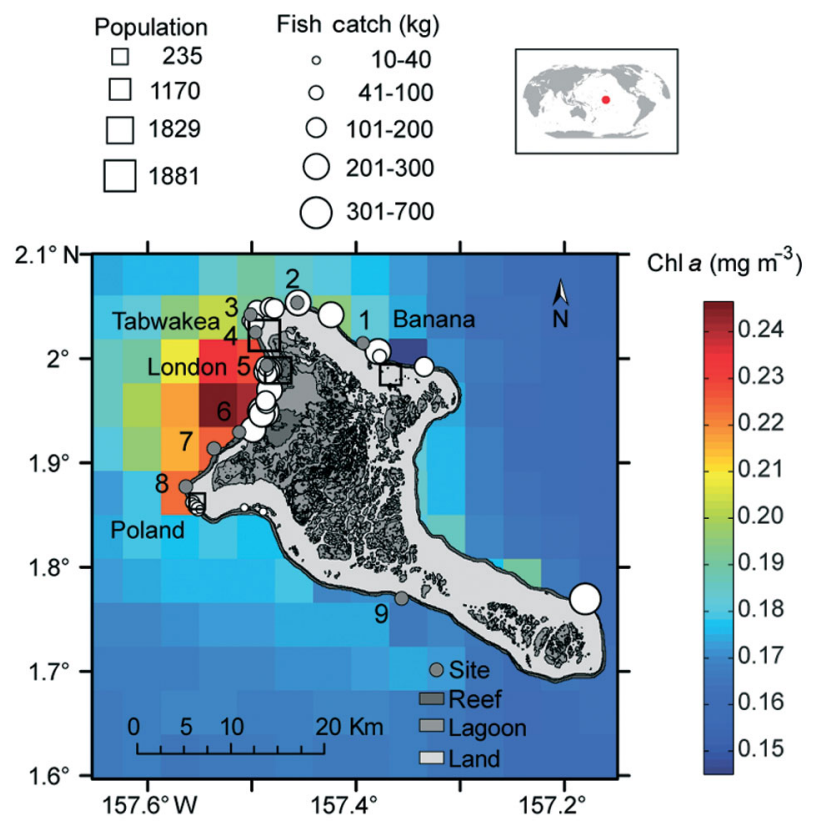

Fig. 2. Kiritimati Island, with average monthly chlorophyll a concentration (from the MODIS satellite), FORAM Index sites (gray circles and numbers), fish catch (white circles), and major population centers (squares and names; adapted from Walsh 2011). Location on a world map is shown at the top (red circle)

rounded by a fringing reef. The human population on Kiritimati has grown rapidly since the 1970 s to over 5000 people (according to the 2005 census), primarily due to a resettlement program; see Sandin et al. (2008) for an account of the historical human population in the Line Islands. There are 4 main population centers on Kiritimati: Tabwakea, London, Banana, and Poland, with populations of 1881, 1829, 1170, and 235, respectively, according to the most recent census from 2005. The population density is approximately 109 people $\mathrm{km}^{-1}$ along the inhabited coastline (Sandin et al. 2008). To estimate relative potential sewage impacts at each site, we calculated a human population metric by dividing the human population of the nearest town by the distance to each site; this metric was normal after log-transformation. Data on fishing pressure and oceanographic conditions were collected previously by Walsh (2011).

Fishing pressure is concentrated in the north, and at the most heavily fished sites up to $445 \mathrm{~kg}$ of fish are caught per $\mathrm{km}$ of coastline per week, while $<1 \mathrm{~kg}$ $\mathrm{km}^{-1} \mathrm{wk}^{-1}$ is caught at sites away from the population centers (Walsh 2011). Island wake upwelling, where turbulent flow caused by the presence of an island disturbs ocean currents, causes mixing and the vertical transport of nutrients (Hasegawa et al. 2004). On Kiritimati, island wake upwelling results in higher productivity on the northwestern side of the atoll compared to other parts of the atoll, visualized as average monthly chlorophyll a (chl a) from the MODIS satellite from the period 16 September 2002 to 16 August 2007 (Fig. 2; Walsh 2011).

\section{Sediment sample collection}

A small scoop of about $100 \mathrm{~g}$ of surface sediment was collected in 3 random locations (A, B, C) from sand patches or channels at 10 to $12 \mathrm{~m}$ water depth on the fore-reef at all sites shown in Fig. 2, and placed in plastic zip-top bags. Upon return to land, samples were drained of seawater and approximately 20 to $30 \mathrm{ml}$ of ethanol saturated with Rose Bengal stain were added to each sample bag. Sample bags were then gently mixed to ensure that all grains were in contact with the ethanol and stain. Samples remained in the ethanol solution for at least $1 \mathrm{wk}$ until return to the laboratory, where they were washed with deionized water over a $63 \mu \mathrm{m}$ sieve before drying in a $50^{\circ} \mathrm{C}$ oven. Three samples were lost in transit before processing: 1 from Site 7, and 2 from Site 6. All sites (except 9) were previously visited by $\mathrm{S}$. Walsh for survey data collection (as discussed in Walsh 2011).

To serve as a comparative baseline, 4 sediment samples were also collected and processed in the same way described above from Kingman Reef (approximately $700 \mathrm{~km}$ NW of Kiritimati) on expeditions in 2005 and 2010. Kingman Reef is uninhabited and closed to fishing, with as close to a pristine fish community as is known (Sandin et al. 2008).

\section{Foraminiferal community and FI}

Rose Bengal stains live foraminifera (or recently dead individuals: Murray \& Bowser 2000; but for the time-scale relevant here, we considered these to be alive) a deep pink color (Fig. 3), allowing the separation of individuals that were alive or dead at the time of collection. For each sediment sample, at least 60 individual foraminifera of both the live and dead variety (for a total of at least 120 ind. site $^{-1}$ ) were picked from the bulk sediment samples using standard techniques (e.g. Hallock et al. 2003) at the Australian Nuclear Science and Technology Organization (ANSTO). Standard techniques include methodically searching through dried sediment sprinkled on a gridded tray under a binocular dissecting microscope; all foraminifera from a particular 


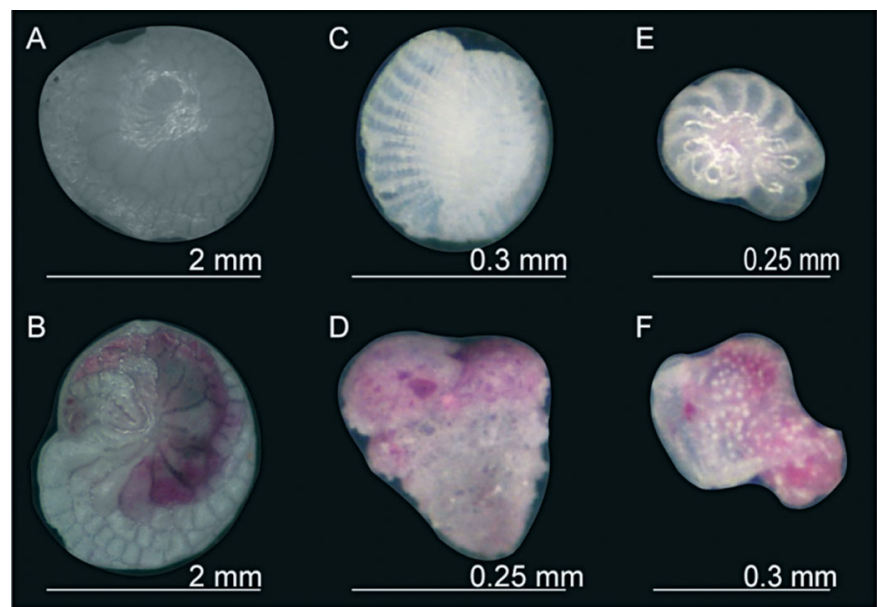

Fig. 3. Examples of dead (unstained) and live (stained) foraminifera of each type used in the FORAM Index calculation: (A) dead mixotrophic Heterostegina sp., (B) live mixotrophic Heterostegina sp., (C) dead heterotrophic Sigmohauerina sp., (D) live heterotrophic Textularia sp., (E) dead opportunistic Elphidium sp., (F) live opportunistic Bolivina tortuosa

grid-square were picked before moving onto the next square, until the requisite number was reached. Foraminifera were identified to genus and separated into mixotrophic, heterotrophic, or opportunistic groupings (Table 1) and placed into archival sample slides. The picked samples were then counted and the FI calculated using the equation:

$$
\mathrm{FI}=\left(10 \times P_{\mathrm{s}}\right)+\left(2 \times P_{\mathrm{h}}\right)+\left(P_{\mathrm{o}}\right)
$$

where $P_{\mathrm{s}}$ is the proportion of the total sample comprised of symbiont-bearing (or mixotrophic) taxa, $P_{\mathrm{h}}$ is the proportion of the total sample comprised of heterotrophic taxa, and $P_{\mathrm{o}}$ is the proportion of the total sample comprised of opportunistic taxa. Hallock et al. (2003) recommended picking at least 150 foraminifera for each FI calculation; however, in many samples, foraminifera were quite rare and the majority of the sediment was composed of coral and calcareous algal fragments, sponge spicules, and other material. In order to determine whether a smaller sample size was acceptable, we produced modified collector's curves, similar to those used to estimate whether a given sample size is adequate to estimate species diversity (Pielou 1977). A range of sample sizes $(100-240)$ were selected from both the live and dead fraction from 3 samples, and the trophic group of foraminifera was noted down in order of selection. From these ordered data, the FI and $95 \%$ confidence intervals were calculated using bootstrapping (10 000 iterations) for increasing sample sizes starting from 10 total picked individuals (Fig. 4); after approximately 50 specimens were selected, the FI did not change appreciably. Therefore, the use of fewer foraminifera was deemed acceptable from sparsely populated samples to minimize personhours devoted to picking samples, though given enough time eventually 150 specimens could have been obtained from our samples. The FI identified as Site 9 is the average of 6 total samples pooled from 2 sites approximately $5 \mathrm{~km}$ apart (location in Figs. 2 \& 5 is mid-point) because no equivalent survey sites from Walsh (2011) existed.

The Kingman Reef samples were used to determine whether there was any bias towards one type of foraminifera over another in either the live or dead fraction due to post-depositional or other processes, since theoretically a reef with a steady-state foraminiferal assemblage should have no difference in FI between the live and dead fractions.

Table 1. Foraminiferal genera identified in samples and trophic group assignments

\begin{tabular}{|ll|}
\hline Trophic group & Genus \\
\hline Mixotrophic & Alveolinella \\
& Amphistegina \\
& Heterostegina \\
& Peneroplis \\
& Sorites \\
& Asanonella \\
Cibicides \\
Conicospirillina \\
Cymbaloporella \\
Discorbinella \\
Edentostomina \\
Eponides \\
Epistomaroides \\
Eupatellinella \\
Lamarckina \\
Milliolinella \\
Planorbulina \\
Pseudomassillina \\
Quinquelocilina \\
Reusella \\
Rosalina \\
Rotorbis \\
Sigmohauerina \\
Siphoniferoides \\
Spirillina \\
Spiroloculina \\
Textularia \\
Triloculina \\
Uvigerina \\
Bolivina \\
Bolivinella \\
Elphidium \\
Nodosaria \\
Nonion \\
\\
\\
\\
\end{tabular}



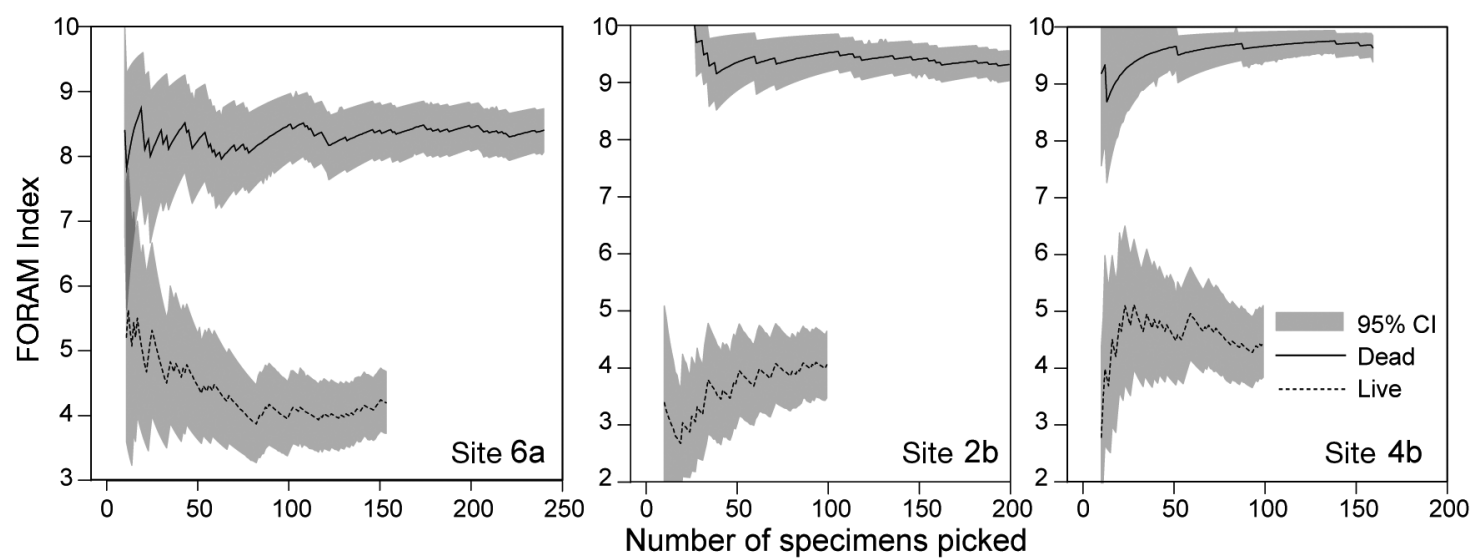

Fig. 4. Collector's curves of the FORAM Index (FI) with increasing numbers of specimens for individual samples from Sites 6, 2, and 4 (1 of 3 replicates shown per site). Black lines are bootstrapped FI values, and gray shading shows bootstrapped $95 \%$ confidence intervals. Curves constructed using dead specimens have solid lines; those using live are dashed

\section{Grain size analysis}

All remaining unpicked material $(>63 \mu \mathrm{m}$ in diameter due to sieving to remove mud and silt-sized particles and wash excess stain from samples) was weighed and dry sieved to separate out material $>2.36 \mathrm{~mm}$ and $>1 \mathrm{~mm}$ in diameter. Each of these separate fractions was then weighed. Material $63 \mu \mathrm{m}$ to $1 \mathrm{~mm}$ in diameter was analyzed for volume percentage in different size classes using a Malvern Mastersizer 2000 laser particle sizer. Volume percentages were assumed to be equivalent to weight percentages to be comparable to percent contribution of coarse material, and weight percents for all size classes were computed, from which the median grain size was identified (where $\sim 50 \%$ of material was smaller than that size fraction).

\section{Radiocarbon analyses}

Five samples were selected for radiocarbon dating, using the most intact and pristine large unstained Heterostegina sp. specimens available from different sites. One specimen was dated from each of Sites 2 and 5, 2 specimens from Sites 1 and 9, and 3 specimens from Site 3 . When more than 1 specimen was used in a sample, shells of similar size were used. Shells were pretreated by leaching in $0.001 \mathrm{M} \mathrm{HCl}$ for $3 \mathrm{~min}$, then rinsed 3 times with MilliQ water and dried in a $60^{\circ} \mathrm{C}$ oven overnight. Pre-treated samples were then converted to graphite for ${ }^{14} \mathrm{C}$ analysis following the methods of Hua et al. (2001), and analyzed at ANSTO's STAR accelerator mass spectrometry facility (Fink et al. 2004). Measured ${ }^{14} \mathrm{C}$ values in Fraction
Modern Carbon $\left(\mathrm{F}^{14} \mathrm{C}\right)$ of these samples were converted to calendar dates using the OxCal calibration program v4.1.3 (Bronk Ramsey 2009). The post-bomb $\mathrm{F}^{14} \mathrm{C}$ data for the surface ocean in the central Pacific, which were used as the radiocarbon calibration curve here, were derived from $\Delta^{14} \mathrm{C}$ from an annuallybanded coral from Fanning Island $\left(3^{\circ} 52.5^{\prime} \mathrm{N}\right.$, $159^{\circ} 19.3^{\prime} \mathrm{W}$ ) for the period 1949 to 1979 (Druffel $1987)$ and the weighted average values of the nearest 6 surface water samples $\left(0-7^{\circ} \mathrm{N}, 151^{\circ} \mathrm{W}\right)$ collected in 1991 during the World Ocean Circulation Experiment (WOCE; Goyet et al. 1996) and in 2006 from the Climate Variability and Predictability (CLIVAR) project (Feely et al. 2006; see Fig. S1 in the supplement at www.int-res.com/articles/suppl/m456p087_supp.pdf).

\section{Statistical analyses}

Differences in mean FIs were compared (1) between the live and dead fraction using a paired $t$-test with unequal variance and (2) in the dead fraction, between sites inside and outside the main upwelling zone using a Welch's t-test (R version 1.13). Sites 4, 5, 6,7 , and 8 are inside the upwelling zone, while Sites $1,2,3$, and 9 are outside the upwelling zone (as defined by Walsh 2011).

We performed a principal components analysis (PCA) to explore associations between changes in the FI over time and spatial differences in coral reef community structure, which are correlated with spatial differences in fishing and upwelling (Walsh 2011). The FI of the live fraction at each site was subtracted from the dead fraction, to control for unobservable heterogeneity across sites (e.g. differences 
in exposure and topography). Coral reef community variables included the proportion of benthos comprised of reef-builders (corals and crustose coralline algae), proportion comprised of macroalgae and turf algae, total fish biomass, as well as chl $a$ and fishing effort (for details on data collection, see Walsh 2011). Survey data from Walsh (2011) were collected at Sites 1 to 8. Given that no survey data were collected at Site 9, the average of the survey data from the nearest 2 survey sites from Walsh (2011) to Site 9 was used here, after first checking that the benthic cover was similar by analyzing 50 random points from 3 photographs per site using the same method employed by Walsh (2011). The average coral cover between our Site 9 here and the 2 sites from Walsh (2011) was identical at $58 \%$. All survey data were standardized and tested for normality with the Shapiro-Wilkes test ( $\mathrm{R}$ version 1.13). All variables were normal, except for fishing effort, which was normal after being log transformed. Incorporation of other variables such as top predator biomass and herbivore biomass were also explored; however, those variables were not normal (and no transformations resulted in normality).

We then investigated the relative effects of human impacts ('Human') and upwelling (represented by chl a) on the difference in FI by estimating models representing all combinations of the main and interactive effects of these 2 factors using ordinary least squares where $\beta_{0}, \beta_{1}, \beta_{2}$, and $\beta_{3}$ represent the coefficients on the predictor variables and the constant:

$$
\begin{aligned}
\text { Difference in FI }= & \beta_{0}+\beta_{1} \text { chl } a+\beta_{2} \text { Human }+ \\
& \beta_{3} \text { chl } a \times \text { Human } \\
\text { Difference in FI }= & \beta_{0}+\beta_{1} \text { chl } a+\beta_{2} \text { Human } \\
\text { Difference in FI }= & \beta_{0}+\beta_{1} \text { chl } a \\
\text { Difference in FI }= & \beta_{0}+\beta_{2} \text { Human }
\end{aligned}
$$

We estimated these models using 2 indicators of human impacts: fishing effort $(\mathrm{h} \times$ fishermen $\mathrm{km}^{-1} \mathrm{wk}^{-1}$ ) and potential sewage runoff (represented by the log of the human population metric). Chl a was not correlated with fishing effort or the log of the population metric $(\mathrm{R}=0.35,0.22 ; \mathrm{p}=0.35,0.58$, respectively), which made this a valid approach. In contrast, fishing effort and the log of the human population were significantly correlated despite some spatial variation in the patterns of these indicators of human impacts (e.g. at Site 2, fishing effort was high while the population metric was low; $\mathrm{R}=0.81, \mathrm{p}=$ 0.01). We computed the corrected Akaike information criterion of each model, using both indicators of human impacts, to determine which had the best fit. We also computed the Akaike weights $(w)$ of each model to assess the probability that each model, or a set of models, best explains the data (Johnson \& Omland 2004). We then tested whether median grain size was significantly correlated with FI in the live or dead fractions using Pearson's correlations in R.

\section{RESULTS}

The mean $( \pm \mathrm{SD})$ FI of the living fraction of all samples $(4.6 \pm 1.26)$ was significantly lower than that of the dead fraction $(9.1 \pm 0.57)$, indicating an increase in the relative abundance of heterotrophic and/or opportunistic taxa over time (Table $2 ; t=15.54, \mathrm{df}=8$, $\mathrm{p}<<0.001$ ). The lowest FI values in the live fraction were found at Sites 4 and 5, which are closest to the 2 main population centers of Tabwakea and London, where potential sewage impacts as well as fishing are also concentrated (Fig. 5). In contrast, there was no significant difference between live and dead assemblages from Kingman Reef $(t=1.35, \mathrm{df}=3, \mathrm{p}=0.27)$.

The impact of island wake upwelling was not apparent in the spatial patterns in FI. Linear models relating chl $a$ and the dead, live (not shown), and dead-live FI resulted in poor fits (Table 3). The mean dead FI for those sites inside the upwelling zone was lower (Sites 4, 5, 6, 7, 8: mean 8.8) than outside (Sites $1,2,3,9$ : mean 9.4), but the difference was not significant $(t=-1.89, \mathrm{df}=5.54, \mathrm{p}=0.11)$.

The first principal component explained $68 \%$ of the variance in community structure while the second component explained an additional $21 \%$. Changes along the first principal component represent a shift from communities with a high total fish biomass and reef-builder cover, to ones with low fish biomass and high algal cover. Larger decreases in the FI over time (indicating an increase in heterotro-

Table 2. Mean \pm SD FORAM Index $(F I)$ for dead and live fractions as well as the number of samples from each site (see Fig. 2 for site locations)

\begin{tabular}{|lccc|}
\hline Site & Dead FI & Live FI & Samples \\
\hline 1 & $9.4 \pm 0.12$ & $5.6 \pm 0.51$ & 3 \\
2 & $9.3 \pm 0.11$ & $4.1 \pm 0.07$ & 3 \\
3 & $9.2 \pm 0.72$ & $5.3 \pm 1.10$ & 3 \\
4 & $9.8 \pm 0.13$ & $5.0 \pm 0.67$ & 3 \\
5 & $8.2 \pm 1.48$ & $2.5 \pm 0.12$ & 3 \\
6 & 8.3 & 3.0 & 1 \\
7 & $8.7 \pm 0.25$ & $3.8 \pm 0.72$ & 2 \\
8 & $9.7 \pm 0.21$ & $5.3 \pm 0.54$ & 3 \\
9 & $9.2 \pm 0.56$ & $6.3 \pm 0.75$ & 6 \\
Kingman Reef & $5.7 \pm 1.09$ & $5.4 \pm 1.54$ & 4 \\
\hline
\end{tabular}



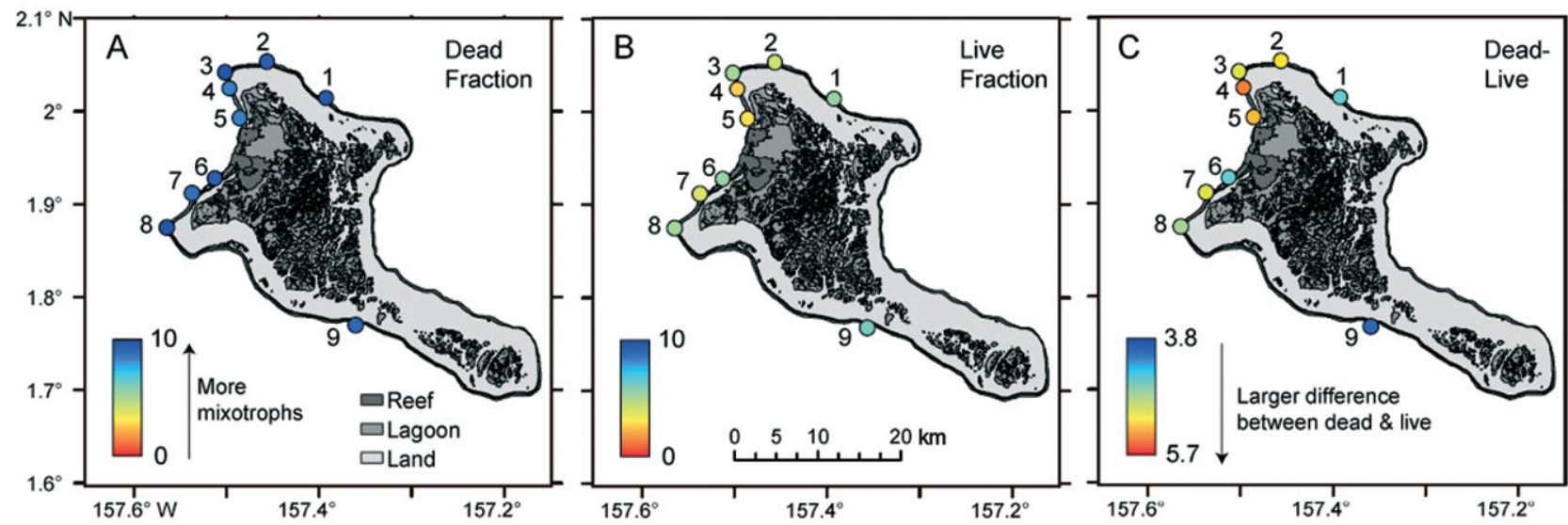

Fig. 5. Kiritimati, showing FORAM Indices (A) in the dead fraction, (B) in the live fraction, and (C) the difference between the dead and live fraction at each site. Note difference in scale in $(C)$

Table 3. Models tested to explain differences in FORAM Index (FI) between dead and live assemblage and associated corrected Akaike information criterion $\left(\mathrm{AIC}_{\mathrm{c}}\right)$ and Akaike weights $(w)$, where $\beta_{0}, \beta_{1}, \beta_{2}$, and $\beta_{3}$ represent the coefficients on the predictor variables and the constant. Fishing is measured as standard fishing effort $\left(\mathrm{h} \times\right.$ people $\left.\mathrm{km}^{-1} \mathrm{wk}^{-1}\right)$. Sewage is the log-transformed human population metric (population of nearest town / distance to town), and chlorophyll a $(\mathrm{chl}$ a) is measured as the average monthly concentration $\left(\mathrm{mg} \mathrm{m}^{-3}\right)$

\begin{tabular}{|lccl|}
\hline Model: difference in FI & Parameters & $\mathrm{AIC}_{\mathrm{c}}$ & $w$ \\
\hline$\beta_{0}+\beta_{1}$ chl $a+\beta_{2}$ Fishing $+\beta_{3}$ chl $a \times$ Fishing & 3 & 20.65 & 0.09 \\
$\beta_{0}+\beta_{1}$ chl $a+\beta_{2}$ Sewage $+\beta_{3}$ chl $a \times$ Sewage & 3 & 27.22 & 0.003 \\
$\beta_{0}+\beta_{1}$ chl $a+\beta_{2}$ Fishing & 2 & 16.43 & 0.12 \\
$\beta_{0}+\beta_{1}$ chl $a+\beta_{2}$ Sewage & 2 & 25.09 & 0.009 \\
$\beta_{0}+\beta_{1}$ chl $a$ & 1 & 28.19 & 0.002 \\
$\beta_{0}+\beta_{1}$ Fishing & 1 & 16.35 & 0.72 \\
$\beta_{0}+\beta_{1}$ Sewage & 1 & 21.50 & 0.06 \\
\hline
\end{tabular}

phic or opportunistic foraminifera) were found at sites that were characterized by low total fish biomass and high fishing effort (Fig. 6).

Our multi-model analysis of the relative influence of human impacts and oceanography provided support for a pattern where more heterotrophic foraminifera were associated with higher levels of fishing (Fig. 7). This model, which included only fishing main effects, was by far the most likely $(72 \%)$ model to explain the spatial differences in the change in FI between the live and dead fraction and explained a large amount of the variation in data (adjusted $\mathrm{R}^{2}=0.71$, $\mathrm{p}<0.01$; Fig. 7, Table 3). Models with main effects of both fishing and chl $a$ and both main and interactive effects of fishing and chl a each had less than a $12 \%$ chance of being the best model to explain the differences in FI. The model with only human population main effects had less than a $6 \%$ chance of being the best model, while the model with only chl a main effects was very unlikely to be the best model (Table 3).

Four of the radiocarbon measurements from the analyzed dead Heterostegina sp. shells fell on the

Fig. 6. Principal components 1 and 2 showing that sites (numbered 1 to 9) with the greatest difference between the dead and live FORAM Index (FI difference; see Fig. 5) (indicating an increase in relative abundance of heterotrophic and opportunistic benthic foraminifera over time) also had the lowest abundance of total fish biomass and the highest fishing effort. Left and bottom axes are principal component loadings, while right and top axes are principal component scores 

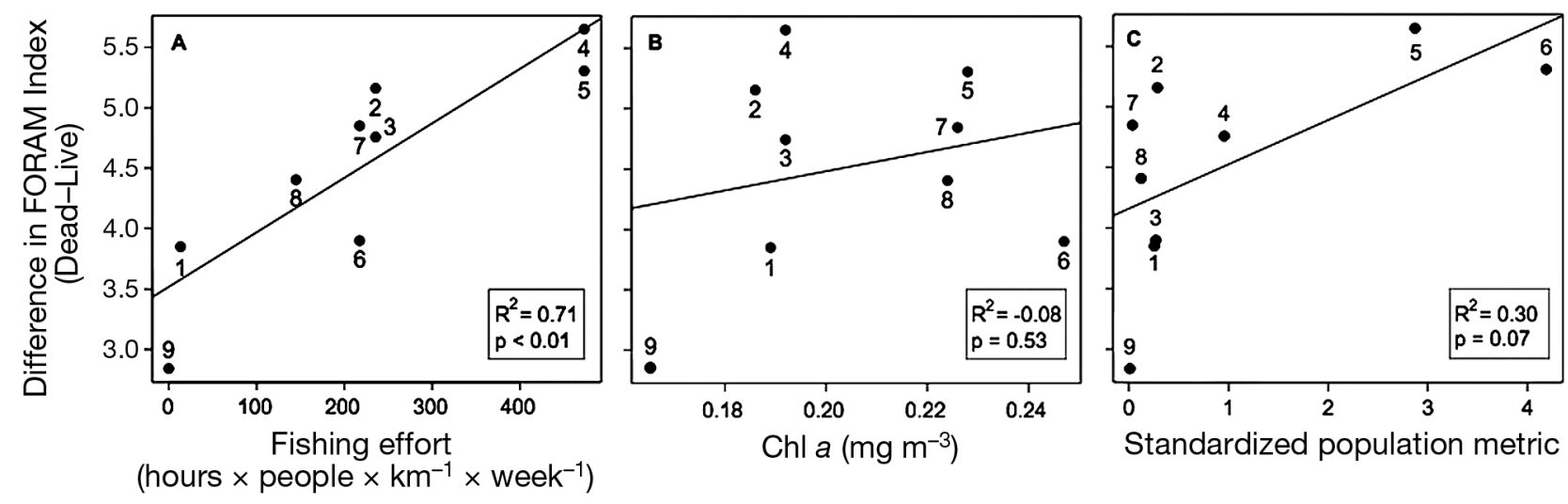

Fig. 7. (A) Difference in FORAM Index between the dead and live fraction at each site (numbers), along with the fitted values of the model 'Difference in FI $=\beta_{0}+\beta_{2}$ Fishing' (line), where 'Fishing' indicates standard fishing effort. (B) Difference in FORAM Index between the dead and live fraction at each site (numbers), along with the fitted values of the model 'Difference in FI $=\beta_{0}+\beta_{2}$ chl $a^{\prime}$ (line). (C) Difference in FORAM Index between the dead and live fraction at each site (numbers), along with the fitted values of the model 'Difference in FI $=\beta_{0}+\beta_{2}$ Sewage' (line). A higher difference in the FI indicates a higher proportion of heterotrophic or opportunistic benthic foraminifera in the live fraction, and a larger decline in water quality

calibration curve at 2 different time periods before and after the bomb-pulse peak in $\left[{ }^{14} \mathrm{C}\right]$, giving 2 different possible age-ranges (Hua 2009), while 1 sample had only 1 possible age-range (1964-1967), though it is possible it was younger than 2006, which was the last point in our calibration curve (Fig. S2 in the supplement at www.int-res.com/articles/suppl/ m456p087_supp.pdf). The 95.4\% confidence intervals of calibrated ages were: Site 1: 1964-1967, Site 2: $1972-1978$ or $1980-2003$, Site 3: $1966-1972$ or $2000-\geq 2006$, Site $5: 1967-1972$ or $1998-\geq 2006$, and Site 6: $1967-1971$ or $2000-\geq 2006$.

\section{DISCUSSION}

We found a temporal shift from autotroph-dominated (dead, mean \pm SD: $9.1 \pm 0.57$ ) to heterotrophdominated (live, mean $4.6 \pm 1.26$ ) benthic foraminiferal assemblages on Kiritimati Island. PCA indicated that sites with larger decreases in FI over time had lower fish biomass and higher fishing effort. In addition, the linear model that included only fishing effort best explained the FI difference; the differences were not explained by spatial patterns in oceanography (chl a). Although we could not definitively separate the effects of fishing from potential sewage effects, these results suggest that human occupation has reduced water quality over the scale of decades on Kiritimati. First we discuss potential issues with our use of the FI as a proxy for recent nutrification, and then we discuss how the FI relates to human impacts and alternative hypotheses.
In order to use the difference between the live and dead FI as a proxy for recent nutrification, we needed to establish that (1) the dead foraminiferal assemblage was, on average, older than the recent human resettlement program and (2) the difference in the assemblages did not arise from preservation bias. Other studies that dated surface sediment foraminifera and mollusk shells have found large age ranges, indicating that time averaging is considerable (on the order of hundreds to $1000 \mathrm{yr}$ ) in reef sediments. Harney et al. (2000) found ages of 649 and 1270 yr from 2 surface sediment samples of approximately 100 foraminifera from Kailua Bay, Hawaii. Kidwell et al. (2005) dated 45 mollusk shells from reef surface sediments in San Blas, Panama, and found a median and maximum age of 120 and $5400 \mathrm{yr}$ old, respectively, with most of the shells in the younger ( $<500$ yr old) range. Similarly, Meldahl et al. (1997) found mollusk shell half-lives between 90 and $550 \mathrm{yr}$ in the taphonomically active zone in the Gulf of California, Mexico. Foraminiferal shells from surface sediments in Choya Bay, Gulf of California, were on average $\sim 2000$ yr old, while foraminifera from Discovery Bay, Jamaica, and Lee Stocking Island, Bahamas, also exhibited wide age ranges of up to $\sim 3000 \mathrm{yr}$ (Martin et al. 1996). Flessa \& Kowalewski (1994) compiled 734 radiocarbon dates for shells of various types including foraminifera from the literature and reported that in nearshore sediments (water depths $<10 \mathrm{~m}$ ), time-averaging of surface deposits was on the order of $1000 \mathrm{yr}$. Bioturbation of reef sediments by organisms such as Calianassa shrimp likely contributes to time-averaging of surface sediments (Tudhope \& Scoffin 1984). 
To establish whether it was appropriate to assume that our death assemblages were indicative of the foraminiferal assemblages before human occupation, we radiocarbon-dated several large unstained foraminifera. The calibrated radiocarbon ages measured here represent minima (the youngest ages) for the unstained dead assemblages, as the shells chosen for analysis were the most visually pristine and intact in a given sample. In the bulk samples from which specimens were chosen for radiocarbon analyses, the majority (60-74\%) of the other mixotrophic foraminifera appeared degraded: broken, abraded, pitted, and/or discolored and are likely older than the pristine tests analyzed here. While site-specific differences in sediment age are likely to occur, and some contribution from very recently live foraminifera must exist, our minimum mean ages of the most pristine specimens of $\sim 5$ or $40 \mathrm{yr}$, and the consistently older ages of sediments from other studies, indicate that the dead assemblages studied here are likely mainly composed of foraminifera that were alive prior to the major increase in human population that began 40 yr ago on Kiritimati.

The shift in the foraminiferal community at Kiritimati does not appear to be a preservation artifact, and suggests that nutrification increased recently. For instance, there was no significant difference between the live and dead FI from Kingman Reef, approximately $700 \mathrm{~km}$ NW of Kiritimati, which has never been populated or fished (Table 2). We also found no significant relationship between median grain size and live or dead FI in our samples $\left(\mathrm{R}^{2}=\right.$ $0.003,0.060 ; \mathrm{p}=0.99,0.79$, respectively; Fig. S3 in the supplement at www.int-res.com/articles/suppl/ m456p087_supp.pdf). While there is a potential for the dead assemblages to be biased towards mixotroph domination, which tend to be larger and more robust to damage or loss, not all heterotrophic genera found in this study were small and fragile; indeed Eponides spp., Siphoniferoides spp., and Textularia spp. are also large and robust and were quite common in both the live and dead assemblages. The lack of significant differences in live and dead FI at Kingman Reef as well as the lack of a relationship between FI and grain size at Kiritimati suggest that the observed changes at Kiritimati are biologically significant and not fully artifacts of preservation or other bias. Indeed, Hallock et al. (2003) reported a similar decline in magnitude of the FI from samples of live foraminifera collected in Key Largo at 2 known dates spanning a similar time period (1961 versus 1992: decline from an average of 7.09 to 2.91 ).
The spatial differences in the change in FI between dead and live assemblages around Kiritimati were strongly associated with differences in fishing effort and related changes in the reef community. Because fishing effort and the population metric were correlated, we cannot directly rule out the influence of potential sewage impacts. However, other evidence suggests that fishing may be more important in driving recent nutrification than sewage. Dinsdale et al. (2008) found no significant differences between the nitrogen isotopic composition of particulate organic matter in water samples from the most heavily populated section of coastline on Kiritimati and from Kingman Reef; however, the mean at Kiritimati was $1.5 \%$ heavier than at Kingman. Risk \& Erdmann (2000) found nitrogen isotope enrichment of this magnitude in stomatopod tissues from uninhabited versus reefs near small villages in Indonesia, which suggests the possibility of direct human influence on water quality, through discharge of sewage. However, the population density at the Risk \& Erdmann (2000) impacted sites was much higher ( $\geq 2000$ people $\mathrm{km}^{-2}$ ) than at Kiritimati ( 110 people $\mathrm{km}^{-1}$ of coastline; Sandin et al. 2008), suggesting that sewage impacts at Kiritimati may be more diluted. These nitrogen isotopic signatures could also be imparted by oceanographic differences between islands, for instance due to differences in the isotopic composition of upwelled nitrate (Rafter et al. 2012). Dinsdale et al. (2008) estimated that human activity adds $400 \mathrm{~kg}$ of nitrogen $\mathrm{km}^{-1}$ of inhabited coastline per year into the waters around Kiritimati. In contrast, at the peak sewage discharge in 1977, Kaneohe Bay, Oahu, received approximately $5840 \mathrm{~kg}$ nitrogen $\mathrm{km}^{-1} \mathrm{yr}^{-1}$ (Smith et al. 1981). Kaneohe Bay is also a partially enclosed water body with restricted water flow, while the studied reefs in Kiritimati are exposed to the open ocean. The relatively small amount of sewage is therefore likely greatly diluted and appears to be a less important factor than fishing in affecting nutrification, as indicted by the better correlation between the change in FI and fishing effort than with our population metric. These results are consistent with the hypothesis that fishing has had a significant indirect effect on the benthic foraminiferal assemblage through changes in trophic structure and nutrient cycling in Kiritimati over the timescale of the past few decades. However, we cannot rule out the influence of sewage, and direct measures on changes in nutrient cycling due to fishing and subsequent effects on water quality are needed to test this mechanism. 
A reduction in fish biomass may lead to increased nutrient availability (by reducing the relative size of that nutrient pool; Kitchell et al. 1979), potentially stimulating algal growth; likewise, reduced grazing by herbivores can also lead to an increase in macroalgal and turf algal biomass (McClanahan \& Shafir 1990, Mumby et al. 2006, Hughes et al. 2007, Mörk et al. 2009). While macroalgae and turf algae are well known to cause coral degradation, for instance by exacerbating coral disease (Smith et al. 2006), reducing coral growth rates and fitness (Tanner 1995, Vermeij et al. 2010), and impeding the ability of coral larvae to settle (Kuffner et al. 2006), indirect effects of increased macroalgal and turf algal abundance on water quality have yet to be fully explored. Fishing may indirectly lead to increased microbe abundances and community shifts towards more pathogenic microbes that feed on dissolved organic carbon released from algae (Jackson et al. 2001, Dinsdale et al. 2008, Haas et al. 2010, Wild et al. 2010). Fishing can therefore impact water quality by increasing nutrient availability, microbe abundances, and turbidity (for instance through phytoplankton blooms). The reduction in the FI between the dead assemblage and the live assemblage indicates that since human occupation and fishing on Kiritimati, water quality has in fact declined. Indeed, the dead fraction of the foraminiferal assemblages were all autotroph-dominated on Kiritimati before human occupation, though small spatial differences may have occurred due to island wake upwelling. A dramatic shift in the benthic foraminiferal assemblage in all locations around Kiritimati has occurred in recent decades, suggesting that the recent effects of human impacts on these coral reefs is larger than natural variation in nutrient delivery due to upwelling.

Changes in the benthic foraminiferal community are similar to those observed in the microbial community. Dinsdale et al. (2008) found that of 4 of the northern Line Islands, Kiritimati (the island with the highest fishing pressure) had the highest levels of microbes (bacteria and archaea) and virus-like particles. These types of microbes can be separated into similar trophic groups as benthic foraminifera: symbiont-bearing, heterotrophic, and pathogenic; Kiritimati had the highest absolute and relative levels of heterotrophs and potential pathogens of the studied islands (Dinsdale et al. 2008).

Although there are other factors that could affect the FI aside from fishing and sewage, such as water depth, lagoon outflow, and other land-based runoff, we find little evidence to suggest that they explain the observed patterns. Water depth should influence the FI (due to reductions in light, needed by autotrophs, with depth), but Hallock et al. (2003) reported that the FI appears stable in water depths $<20 \mathrm{~m}$, and Schueth \& Frank (2008) found no differences in FI in samples collected at 1 and $12 \mathrm{~m}$ depth. If dead fraction sediments had been transported from shallower water, no significant difference in observed FI would be expected; if transported from deeper to shallower water, we would expect the dead fraction to have lower FI values (higher heterotroph abundance) than observed. In addition, grain size is unrelated to FI, so spatial differences in sediment sorting through wave activity or other controls on grain size cannot explain the patterns observed here. The lagoon outlet is near to the major towns and centers of fishing and upwelling; however, net flow is into the lagoon (Walsh 2011). Kiritimati does not experience other major runoff impacts; for instance there is no heavy industry to contribute heavy metal runoff (Sandin et al. 2008), and as Kiritimati is a coral atoll, rainfall does not cause sediment runoff, as on reefs near high islands and continents.

Significant human impacts on Kiritimati reefs only began in the past few decades, yet large and significant changes in benthic foraminiferal assemblages have already occurred. Observed differences in fish, coral, and algae abundances across the Line Islands (Sandin et al. 2008) and around Kiritimati (Walsh 2011) indicate that many of Kiritimati's reefs are in poor condition due to fishing. Sites with high fishing have high macroalgal and turf algal cover and low coral cover while sites with little to no fishing are dominated by live coral cover and have extremely high levels of fish biomass. In addition, recent observations indicate that even at the most degraded sites, where live coral cover is $<5 \%$, live coral likely dominated in the past as evidenced by in situ dead corals underneath a thin veneer of sediment, turf, and macroalgae (J. Carilli pers. obs.). This study found that on the scale of decades, after human occupation, water quality declined on Kiritimati as reflected in the benthic foraminiferal assemblages; the change in foraminiferal assemblages reflects evidence from other work showing ecosystem-wide changes in trophic structure on impacted reefs. The observed changes on Kiritimati were best explained by fishing, which may indirectly affect water quality through changes in trophic structure and nutrient cycling, an overlooked mechanism that needs future experimental study to verify and understand. 
Acknowledgements. We thank J. Baum, R. Walsh, R. Trebilco, M. Kospartov, and P. Illidge for support in the field, and J. Jackson for providing sediment material from Kingman Reef. Thanks to E. Silbert for help picking foraminifera and Q. Hua for help preparing samples for radiocarbon analysis and calibrating radiocarbon dates. The manuscript was improved by the thoughtful comments of P. Hallock, R. Norris, C. Reymond, and S. Uthicke. This work was supported by a Mia J. Tegner Memorial Research Grant (J.C.), an Australian Nuclear Science and Technology postdoctoral fellowship (J.C.), and a Rufford Small Grant for Nature Conservation (no. 68.05.09; S.W.).

\section{LITERATURE CITED}

Bellwood DR, Hughes TP, Folke C, Nystrom M (2004) Confronting the coral reef crisis. Nature 429:827-833

Bronk Ramsey C (2009) Bayesian analysis of radiocarbon dates. Radiocarbon 51:337-360

Burkepile DE, Hay ME (2006) Herbivore vs. nutrient control of marine primary producers: context-dependent effects. Ecology 87:3128-3139

Carlson CA, Giovannoni SJ, Hansell DA, Goldberg SJ and others (2002) Effect of nutrient amendments on bacterioplankton production, community structure, and DOC utilization in the northwestern Sargasso Sea. Aquat Microb Ecol 30:19-36

Carnahan EA, Hoare AM, Hallock P, Lidz BH, Reich CD (2008) Distribution of heavy metals and foraminiferal assemblages in sediments of Biscayne Bay, Florida, USA. J Coast Res 24:159-169

> Chapin FS III, Walker BH, Hobbs RJ, Hooper DU, Lawton JH, Sala OE, Tilman D (1997) Biotic control over the functioning of ecosystems. Science 277:500-504

> Chartock MA (1983) The role of Acanthurus guttatus (Bloch and Schneider 1801) in cycling algal production to detritus. Biotropica 15:117-121

Daskalov GM (2002) Overfishing drives a trophic cascade in the Black Sea. Mar Ecol Prog Ser 225:53-63

> DeMartini EE, Friedlander AM, Sandin SA, Sala E (2008) Differences in fish-assemblage structure between fished and unfished atolls in the northern Line Islands, central Pacific. Mar Ecol Prog Ser 365:199-215

> Dinsdale EA, Pantos O, Smriga S, Edwards RA and others (2008) Microbial ecology of four coral atolls in the Northern Line Islands. PLoS ONE 3:e1584

Druffel ERM (1987) Bomb radiocarbon in the Pacific: annual and seasonal timescale variations. J Mar Res 45: 667-698

> Dubinsky Z, Stambler N (1996) Marine pollution and coral reefs. Glob Change Biol 2:511-526

> Dulvy N, Freckleton RP, Polunin NVC (2004) Coral reef cascades and the indirect effects of predator removal by exploitation. Ecol Lett 7:410-416

Feely R, Sabine C, Millero F, Wanninkhof R, Hansell D (2006) Carbon dioxide, hydrographic, and chemical data obtained during the R/V Thomas Thompson cruise in the Pacific Ocean on CLIVAR Repeat Hydrography sections P16N_2006 (Feb. 14 - Mar. 30, 2006). Oak Ridge National Laboratory, Oak Ridge, TN

Fink D, Hotchkiss M, Hua Q, Jacobsen G and others (2004) The ANTARES AMS facility at ANSTO. Nucl Instrum Methods Phys Res Sect B 223-224:109-115

Flessa K, Kowalewski M (1994) Shell survival and time- averaging in nearshore and shelf environments: estimates from the radiocarbon literature. Lethaia 27: 153-165

> Gardner TA, Cote IM, Gill JA, Grant A, Watkinson AR (2003) Long-term region-wide declines in Caribbean corals. Science 301:958-960

Goyet C, Guenther PR, Keeling CD, Talley LD (1996) Carbon dioxide, hydrographic, and chemical data obtained during the R/V Thomas Washington cruise TUNES-3 in the equatorial Pacific Ocean (WOCE Section P16C). Oak Ridge National Laboratory, Oak Ridge, TN

Graham NAJ, Aimsworth TD, Baird AH, Ban NC and others (2011) From microbes to people: tractable benefits of notake areas for coral reefs. Oceanogr Mar Biol Annu Rev 49:105-136

Haas AF, Jantzen C, Naumann MS, Iglesias-Prieto R, Wild C (2010) Organic matter release by the dominant primary producers in a Caribbean reef lagoon: implication for in situ $\mathrm{O}_{2}$ availability. Mar Ecol Prog Ser 409:27-39

Hallock P (2000) Symbiont-bearing foraminifera: harbingers of global change? Micropaleontology (NY) 46(Suppl 1): 95-104

> Hallock P, Lidz BH, Cockey-Burkhard EM, Donnelly KB (2003) Foraminifera as bioindicators in coral reef assessment and monitoring: the FORAM index. Environ Monit Assess 81:221-238

> Harney J, Grossman EE, Richmond BM, Fletcher CH III (2000) Age and composition of carbonate shoreface sediments, Kailua Bay, Oahu, Hawaii. Coral Reefs 19: 141-154

Hasegawa D, Yamazaki H, Lueck RG, Seuront L (2004) How islands stir and fertilize the upper ocean. Geophys Res Lett 31:L16303 doi:10.1029/2004GL020143

Hua Q (2009) Radiocarbon: a chronological tool for the recent past. Quat Geochronol 4:378-390

Hua Q, Jacobsen GE, Zoppi U, Lawson EM, Williams AA, Smith AM, McGann MJ (2001) Progress in radiocarbon target preparation at the ANTARES AMS Centre. Radiocarbon 43:275-282

> Huettel M, Wild C, Gonelli S (2006) Mucus trap in coral reefs: formation and temporal evolution of particle aggregates caused by coral mucus. Mar Ecol Prog Ser 307:69-84

Hughes TP (1994) Catastrophes, phase shifts, and largescale degradation of a Caribbean coral reef. Science 265: 1547-1551

> Hughes TP, Rodrigues MJ, Bellwood DR, Ceccarelli D and others (2007) Phase shifts, herbivory, and the resilience of coral reefs to climate change. Curr Biol 17:360-365

> Jackson JBC, Kirby MX, Berger WH, Bjorndal KA and others (2001) Historical overfishing and the recent collapse of coastal ecosystems. Science 293:629

> Jennings S, Greenstreet PR, Reynolds JD (1999) Structural change in an exploited fish community: a consequence of differential fishing effects on species with contrasting life histories. J Anim Ecol 68:617-627

Johnson JB, Omland KS (2004) Model selection in ecology and evolution. Trends Ecol Evol 19:101-108

Kidwell SM, Best MMR, Kaufman DS (2005) Taphonomic trade-offs in tropical marine death assemblages: differential time averaging, shell loss, and probable bias in siliciclastic vs. carbonate facies. Geology 33:729

Kitchell JF, O'Neill RV, Webb D, Gallepp GW, Bartell SM, Koonce JF, Ausmus BS (1979) Consumer regulation of nutrient cycling. Bioscience 29:28-34 
Kuffner IB, Walters LJ, Becerro MA, Paul VJ, RitsonWilliams R, Beach KS (2006) Inhibition of coral recruitment by macroalgae and cyanobacteria. Mar Ecol Prog Ser 323:107-117

Lapointe BE (1997) Nutrient thresholds for bottom-up control of macroalgal blooms on coral reefs in Jamaica and southeast Florida. Limnol Oceanogr 42:1119-1131

Martin RE, Wehmiller JF, Harris MS, Liddell WD (1996) Comparative taphonomy of bivalves and foraminifera from Holocene tidal flat sediments, Bahia la Choya, Sonora, Mexico (Northern Gulf of California): taphonomic grades and temporal resolution. Paleobiology 22: 80-90

McClanahan T, Muthiga NA (1988) Changes in Kenyan coral reef community structure and function due to exploitation. Hydrobiologia 166:269-276

McClanahan TR, Shafir SH (1990) Causes and consequences of sea urchin abundance and diversity in Kenyan coral reef lagoons. Oecologia 83:362-370

Meldahl KH, Flessa KW, Cutler AH (1997) Time-averaging and postmortem skeletal survival in benthic fossil assemblages: quantitative comparisons among Holocene environments. Paleobiology 23:207-229

Mörk E, Sjöö GL, Kautsky N, McClanahan TR (2009) Topdown and bottom-up regulation of macroalgal community structure on a Kenyan reef. Estuar Coast Shelf Sci 84:331-336

Mumby PJ, Dahlgren CP, Harborne AR, Kappel CV and others (2006) Fishing, trophic cascades, and the process of grazing on coral reefs. Science 311:98-101

Murray J (2006) Ecology and applications of benthic foraminifera. Cambridge University Press, Cambridge

> Murray JW, Bowser SS (2000) Mortality, protoplasm decay rate, and reliability of staining techniques to recognize 'living' foraminifera: a review. J Foraminifer Res 30: $66-70$

> Narayan YR, Pandolfi JM (2010) Benthic foraminiferal assemblages from Moreton Bay, south-east Queensland, Australia: applications in monitoring water and substrate quality in subtropical estuarine environments. Mar Pollut Bull 60:2062-2078

Newman MJH, Paredes GA, Sala E, Jackson JBC (2006) Structure of Caribbean coral reef communities across a large gradient of fish biomass. Ecol Lett 9:1216-1227

Pandolfi JM, Bradbury RH, Sala E, Hughes TP and others (2003) Global trajectories of the long-term decline of coral reef ecosystems. Science 301:955-958

Pandolfi JM, Jackson JBC, Baron N, Bradbury RH and others (2005) Are US coral reefs on the slippery slope to slime? Science 307:1725

Pauly D, Christensen V, Dalsgaard J, Froese R, Torres F (1998) Fishing down marine food webs. Science 279: 860-863

Pielou EC (1977) Mathematical ecology. Wiley, New York, NY

Rafter P, Sigman DM, Charles CD, Kaiser J, Haug GH (2012) Subsurface tropical Pacific nitrogen isotopic composition

Editorial responsibility: Tim McClanahan,

Mombasa, Kenya of nitrate: biogeochemical signals and their transport. Global Biogeochem Cycles 26:GB1003 doi:10.1029/ 2010GB003979

> Risk MJ, Erdmann MV (2000) Isotopic composition of nitrogen in stomatopod (Crustacea) tissues as an indicator of human sewage impacts on Indonesian coral reefs. Mar Pollut Bull 40:50-58

Sandin S, Smith JE, DeMartini EE, Dinsdale EA and others (2008) Baselines and degradation of coral reefs in the northern Line Islands. PLoS ONE 3:e1548

Schueth J, Frank TD (2008) Reef foraminifera as bioindicators of coral reef health: Low Isles Reef, northern Great Barrier Reef, Australia. J Foraminifer Res 38:11-22

Smith SV, Kimmerer WJ, Laws EA, Brock RW, Walsh TW (1981) Kaneohe Bay sewage diversion experiment: perspectives on ecosystem responses to nutritional perturbation. Pac Sci 35:279-395

Smith JE, Shaw M, Edwards RA, Obura D and others (2006) Indirect effects of algae on coral: algae-mediated, microbe-induced coral mortality. Ecol Lett 9:835-845

Smriga S, Sandin SA, Azam F (2010) Abundance, diversity, and activity of microbial assemblages associated with coral reef fish guts and feces. FEMS Microbiol Ecol 73: 31-42

Tanner JE (1995) Competition between scleractinian corals and macroalgae: an experimental investigation of coral growth, survival and reproduction. J Exp Mar Biol Ecol 190:151-168

Tudhope AW, Scoffin TP (1984) The effects of Callianassa bioturbation on the preservation of carbonate grains in Davies Reef Lagoon, Great Barrier Reef, Australia. J Sediment Res 54:1091

Uthicke S, Altenrath C (2010) Water column nutrients control growth and C:N ratios of symbiont-bearing benthic foraminifera on the Great Barrier Reef, Australia. Limnol Oceanogr 55:1681-1696

Uthicke S, Nobes K (2008) Benthic Foraminifera as ecological indicators for water quality on the Great Barrier Reef. Estuar Coast Shelf Sci 78:763-773

Uthicke S, Thompson A, Schaffelke B (2010) Effectiveness of benthic foraminiferal and coral assemblages as water quality indicators on inshore reefs of the Great Barrier Reef, Australia. Coral Reefs 29:209-225

Vermeij MJA, van Moorselaar I, Engelhard S, Hörnlein C, Vonk SM, Visser PM (2010) The effects of nutrient enrichment and herbivore abundance on the ability of turf algae to overgrow coral in the Caribbean. PLoS ONE 5:e143120

Walsh SM (2011) Ecosystem-scale effects of nutrients and fishing on coral reefs. J Mar Biol 2011:187248

Wild C, Niggl W, Naumann MS, Haas AF (2010) Organic matter release by Red Sea coral reef organisms-potential effects on microbial activity and in situ $\mathrm{O}_{2}$ availability. Mar Ecol Prog Ser 411:61-71

> Woodroffe CD, Morrison RJ (2001) Reef-island accretion and soil development on Makin, Kiribati, central Pacific. Catena 44:245-261

Submitted: August 15, 2011; Accepted: February 19, 2012 Proofs received from author(s): May 16, 2012 